Michał Hinc

Muzeum Piśmiennictwa i Muzyki

Kaszubsko-Pomorskiej w Wejherowie

Instytut Kaszubski w Gdańsku

\title{
O narracji historii Kaszubów na wystawie stałej w Książnicy profesora Gerarda Labudy w Wejherowie
}

Tyle byto zawsze historii Kaszubów, ile w niej było dokonań samych Kaszubów. Ale historia ich będzie trwała tak długo, jak długo imię Kaszubów, ich mowa, ich obyczaj będa stanowiły wartość dla nich samych.

To pierwsze słowa, które dostrzeżemy wchodząc do Książnicy profesora Gerarda Labudy będącej częścią Muzeum Piśmiennictwa i Muzyki Kaszubsko-Pomorskiej w Wejherowie ${ }^{1}$. Uroczyste otwarcie nowego obiektu kulturalnego na mapie powiatu wejherowskiego, czy szerzej Kaszub, nastąpiło 1 października 2020 r., a więc dokładnie dekadę po śmierci patrona placówki².

\footnotetext{
${ }^{1}$ Historią wejherowskiego Muzeum zajmowało się kilku badaczy najczęściej zawodowo związanych z placówką. [Ruchlewski 2019; A. Lubocki, 2021 (tekst w druku); Obracht-Prondzyński 2008: 297-308; Breza 2000; P. Labuda 1972; Kamiński 1971].

${ }^{2}$ Do najważniejszych instytucji muzealnych na mapie Kaszub, które profilowo sklasyfikować można do zajmujących się szeroko pojętą Kaszubszczyzną zaliczyć należy: Muzeum Ziemi Kościerskiej w Kościerzynie, Muzeum Ziemi Puckiej w Pucku, Muzeum w Lęborku, Muzeum Historyczno-Etnograficzne w Chojnicach, Muzeum Kaszubskie w Kartuzach, Muzeum Piśmiennictwa i Muzyki Kaszubsko-Pomorskiej w Wejherowie, Muzeum - Kaszubski Park Etnograficzny we Wdzydzach Kiszewskich, Muzeum Zachodniokaszubskie w Bytowie. Dzieje Kaszubów są też przynajmniej w pewnej części obecne w Muzeum Gdańska, Muzeum Archeologicznym w Gdańsku, Muzeum Narodowym w Gdańsku, Muzeum Gdyni, Muzeum Pomorza Środkowego w Słupsku, Muzeum II Wojny Światowej w Gdańsku.
} 


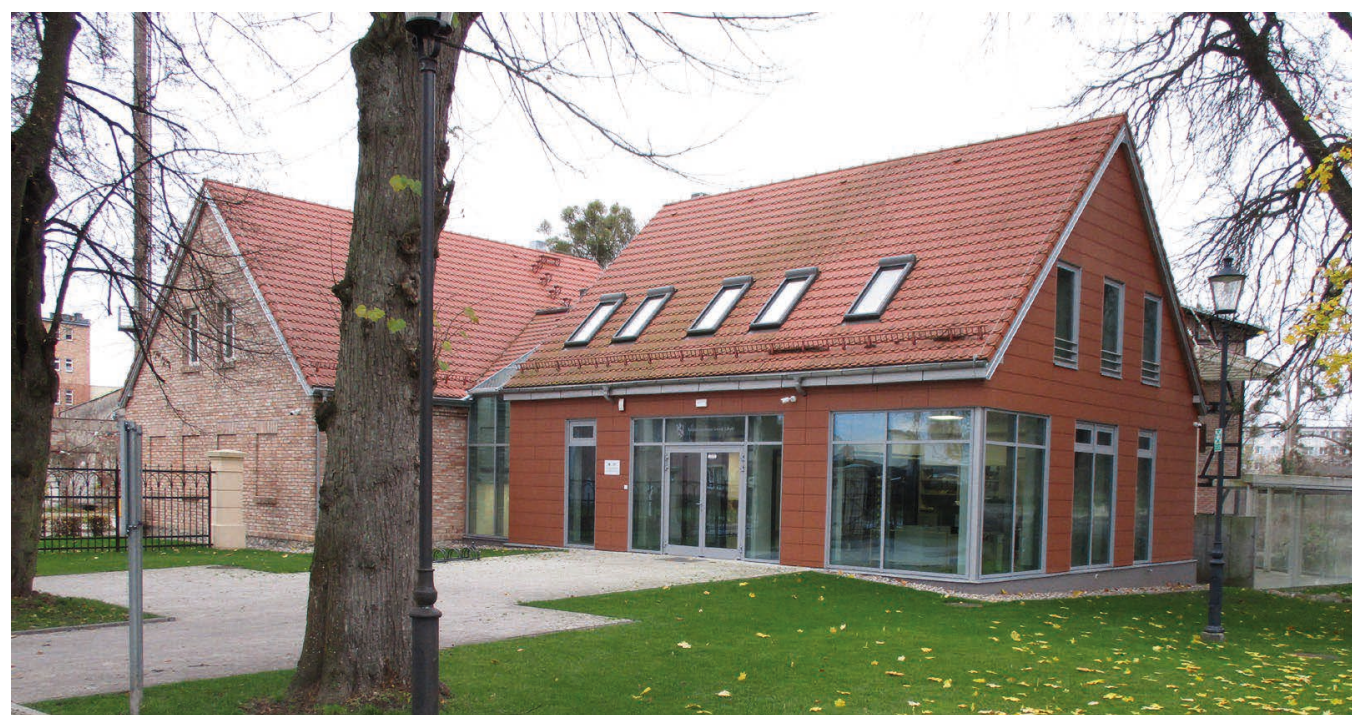

Il. 1. Książnica profesora Gerarda Labudy w Wejherowie (fot. Michał Hinc)

W tym miejscu zmierzamy do sformułowania podstawowych celów przyświecających powstaniu tego artykułu. Ten bowiem zrodził się z potrzeby zasygnalizowania, iż na mapie obiektów muzealnych Pomorza i Polski pojawiła się Książnica będąca integralną częścią Muzeum Piśmiennictwa i Muzyki Kaszubsko-Pomorskiej w Wejherowie. Autor podjął też próbę opisu genezy powstania placówki, jej podstawowych funkcji, a przede wszystkim treści i funkcji poznawczych obecnej tu wystawy stałej poświęconej w znacznej mierze historii Kaszubów, a i oczywiście jej patronowi. Ważne jest też wyjaśnienie, w jaki sposób muzealny zespół postanowił przedstawić dzieje Kaszubów w wystawowej przestrzeni, mając na uwadze metodologię narracji zaproponowaną w wielu pracach przez prof. Gerarda Labudę, którego imię nosi ten nowy obiekt. Istotne jest także to, z jakimi trudnościami mierzyli się pracownicy muzeum pracujący nad scenariuszem wystawy.

Zapewne już teraz pojawiają się podstawowe pytania skąd nazwa Książnica i dlaczego powstała akurat w Wejherowie? Genezę obiektu wiązać należy z osobistą decyzją prof. Gerarda Labudy, potwierdzoną testamentowym zapisem, w którym wyraził on wolę bezpłatnego przekazania swego księgozbioru i archiwum na rzecz Muzeum Piśmiennictwa i Muzyki Kaszubsko-Pomorskiej w Wejherowie [Notatka ze spotkania u prof. Gerarda Labudy w dniu 26 kwietnia 2010 roku, 2011: 675-680]. Darczyńca zastrzegł, że przekazany przez niego księgozbiór (liczący ok. 26 tys. woluminów) i osobiste archiwum winny stanowić osobny zbiór odseparowany od innych muzealiów, sugerując w spotkaniach i rozmowach, że odpowiednim 
miejscem dla tej spuścizny będzie biblioteka stanowiąca część wejherowskiego Muzeum³.

Biblioteka była tylko tymczasową i roboczą nazwą planowanego obiektu. Ze względu na ustawowe i statutowe zadania muzeum, nowy obiekt z przyczyn formalnych nie mógł stać się biblioteką gdyż każdy przekazany tam obiekt zyskał rangę muzealnego zabytku, a to oznacza, że może być udostępniany jedynie na miejscu w czytelni. Finalnie uznano, że planowany obiekt będzie Książnicą ${ }^{4}$ Po wielu poszukiwaniach, ostateczną siedzibą Książnicy stały się przebudowane i dawne budynki oficynowe powstałe w XIX w., znajdujące się tuż przy Pałacu Keyserlingków, obecnej siedzibie Muzeum. Powstanie obiektu poprzedziły liczne wydarzenia promocyjne i kulturalne, a te najważniejsze z nich odbyły się w ogłoszonym przez Zrzeszenie Kaszubsko-Pomorskie Roku Prof. Gerarda Labudy w stulecie urodzin mediewisty w roku $2016^{5}$.

Obiektywne wskazanie przez współczesnych naukowców najważniejszego obszaru badawczego z ponad siedemdziesięcioletniej pracy Gerarda Labudy jest bardzo trudne. To przecież rozmaite obszary dotykające historii kultury [Samsonowicz 2006: 21-27], dziejów wczesnego średniowiecza i początków polskiej państwowości [Michałowski 2002], historii dyplomacji [Labuda 2002], czy wreszcie kompleksowych dziejów Pomorza6 i Kaszubów. Sam Profesor rozwiał te wątpliwości u schyłku życia jasno publicznie deklarując, że to dzieje społeczności, z którą zawsze się identyfikował i której nigdy się nie wyparł były dla niego najważniejsze ${ }^{7}$.

\footnotetext{
${ }^{3}$ Decyzja Gerarda Labudy wynikała z faktu jego związków z wejherowskim muzeum, w którym przez ponad 20 lat pełnił funkcję przewodniczącego Rady Naukowej [Borzyszkowski 2011: 38-39].

${ }^{4}$ Pomysłodawcą nazwy jest Janina Kurowska, starszy kustosz, do 2020 r. kierownik Działu Rękopisów i Starodruków w Muzeum Piśmiennictwa i Muzyki Kaszubsko-Pomorskiej w Wejherowie.

${ }^{5}$ Zanim powstał budynek Książnicy w wejherowskim muzeum mogliśmy zapoznać się z wystawą biograficzną poświęconą Profesorowi autorstwa Grażyny Wirkus, a także ekspozycję pt. Gerard Labuda (1916-2010). Kaszuba w Poznaniu, autorstwa Justyny Grabowskiej-Szmelc i Zuzanny Szwedek-Kwiecińskiej. Z okazji stuletniej rocznicy urodzin Profesora, Zrzeszenie Kaszubsko-Pomorskie ogłosiło rok 2016 Rokiem Gerarda Labudy w związku z czym odbyło się wiele wydarzeń kulturalnych i naukowych upamiętniających tę postać. Więcej na ten temat m.in. w: [Fopke 2017: 106-126].

${ }^{6}$ Seria wieloautorskich monografii naukowych Historia Pomorza wydawanych od $1969 \mathrm{r}$. także jest rezultatem koncepcji i starań Gerarda Labudy. Seria ta jest kontynuowana z zamiarem doprowadzenia dziejów Pomorza do współczesności.

${ }^{7}$ Swoje badawcze plany zapowiadał mieszkając już w Poznaniu: „Zamierzam napisać historię Kaszub, jestem to winien moim ziomkom. Długo nie zdawałem sobie sprawy, jak ciężka drogę przeszli Kaszubi do swego odrodzenia narodowego. Teraz wrócitem do źródeł. Tam zresztą zaczęta się także moja szkoła historii”. [Labuda, 2000: 485].
} 
„Profesorowi Lorencowi ${ }^{8}$ wręczam to główne dzieło mojego życia. To główne dzieło mojego życia" podkreślił Gerard Labuda przekazując swoją najnowszą książkę, monografię pt. Historia Kaszubów w dziejach Pomorza. Czasy średniowieczne [Labuda 2006] podczas uroczystości otwarcia nowego roku akademickiego w auli Uniwersytetu im. Adama Mickiewicza w Poznaniu w 2006 r. ${ }^{9}$ Ta przełomowa publikacja — według Labudy — najważniejsza w jego dorobku naukowym, była zaledwie początkiem na drodze doprowadzenia tej historii aż po czasy nam obecne. Dokończenie tej narracji aż do czasów współczesnych mediewista pozostawił innym znawcom tej historii [Borzyszkowski 1991; 2006: 61-87]. To na kartach tych dziejów Gerard Labuda zrealizował wypracowywany przez lata postulat naukowy mówiący o konieczności pisania nie historii Kaszub lecz historii Kaszubów [Labuda 2006]. Ostatecznie uznał, że „Kaszuby są tam, gdzie żyją i mieszkają Kaszubi. Tej oczywistej prawdy nie zawsze przestrzegali badacze próbujacy ustalić tereny, do których odnosi się nazwa Kaszuby” [Labuda 1996: 204].

Książnica jest jak dotąd pierwszą placówką muzealną w Polsce, w której podstawowym językiem narracji jest jedyny zarejestrowany w Polsce język regionalny-kaszubski ${ }^{10}$. Jest on wykorzystany nie tylko jako pierwszoplanowy język wystawy stałej. Kaszubski jest obecny także w całej przestrzeni budynku Książnicy ${ }^{11}$. Języki polski i angielski również mają tu swoje miejsce, choć pełnią funkcję pomocniczą. Ten zabieg ma na celu nie tylko podkreślenie znaczenia języka regionalnego dla historii i tożsamości Kaszubów, ale też służy pisaniu tej historii z perspektywy tej społeczności. Takie zastosowanie języka kaszubskiego jest też nawiązaniem do tego w jaki sposób Gerard Labuda cenił codzienne posługiwanie się nim. W jednym

\footnotetext{
${ }^{8}$ Chodzi o profesora Stanisława Lorenca, rektora Uniwersytetu im. Adama Mickiewicza w Poznaniu w latach 2002-2008.

${ }^{9}$ Materiał filmowy z tego wydarzenia patrz w: https://www.youtube.com/watch?v=wVfSKt OUqRk [dostęp: 13.11.2021].

${ }^{10}$ „Art. 19. 1. Za język regionalny w rozumieniu ustawy, zgodnie z Europejską Kartą Języków Regionalnych lub Mniejszościowych, uważa się język, który: 1) jest tradycyjnie używany na terytorium danego państwa przez jego obywateli, którzy stanowią grupę liczebnie mniejszą od reszty ludności tego państwa; 2) różni się od oficjalnego języka tego państwa; nie obejmuje to ani dialektów oficjalnego języka państwa, ani języków migrantów. 2. Językiem regionalnym w rozumieniu ustawy jest język kaszubski [pogrubienie M. H.]. Przepisy art. 7-15 stosuje się odpowiednio, z tym że przez liczbę mieszkańców gminy, o której mowa w art. 14, należy rozumieć liczbę osób posługujących się językiem regionalnym, urzędowo ustaloną jako wynik ostatniego spisu powszechnego". (Ustawa z dnia 6 stycznia $2005 \mathrm{r}$. o mniejszościach narodowych i etnicznych oraz o języku regionalnym. Dz. U. 2005, poz.

${ }^{11}$ Teksty pierwotnie były tworzone w języku polskim. Ich tłumaczeniem na język kaszubski, a także korektą zajęli się Tomasz Fopke, Roman Drzeżdżon i Dariusz Majkowski.
} 


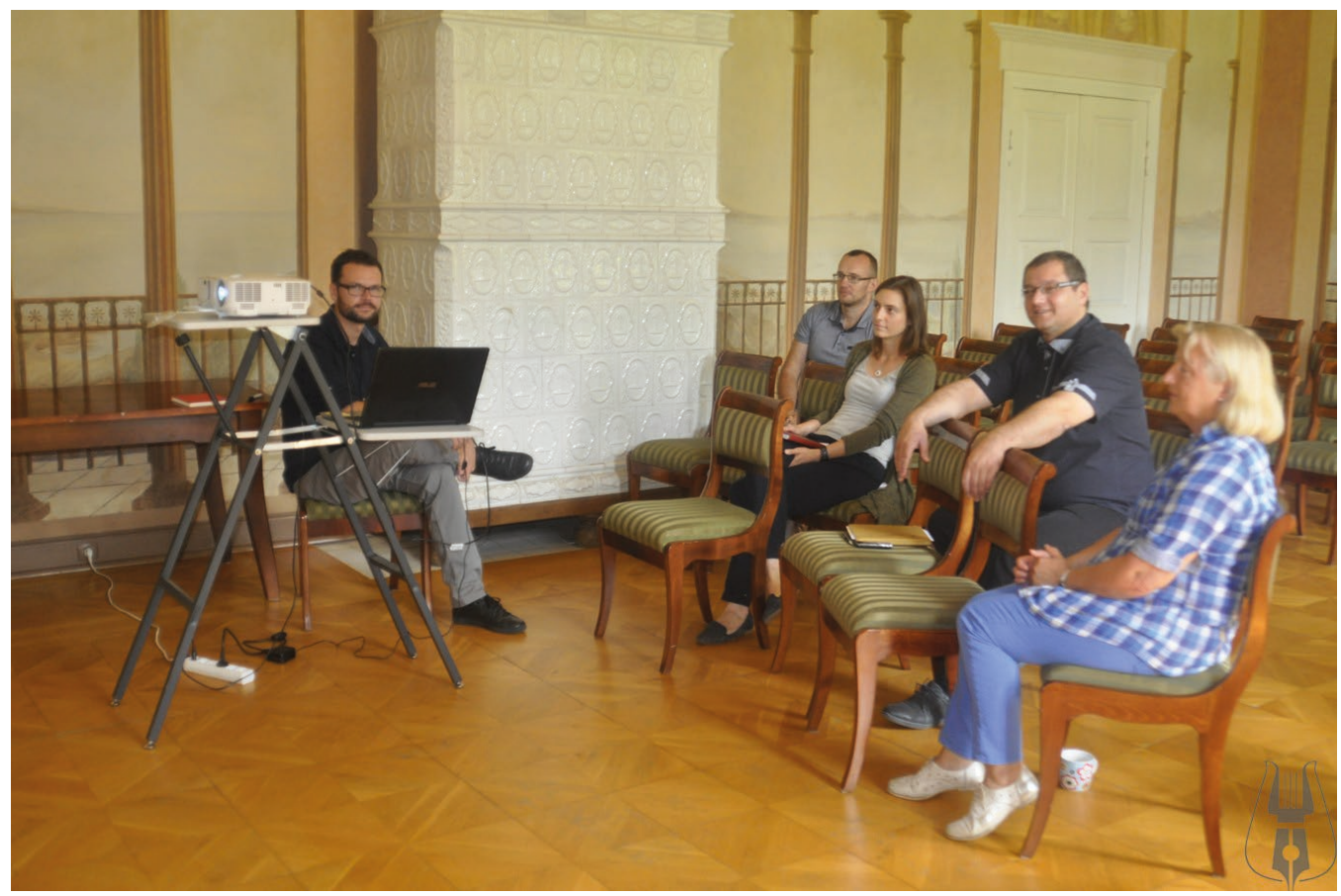

Il. 2. Jedno z roboczych spotkań poświęcone przygotowaniu wystawy stałej w Książnicy. Od lewej: koordynator projektu wystawienniczego Andrzej Hoja, członkowie kuratorskiego zespołu muzealnego: Michał Hinc, Zuzanna Szwedek-Kwiecińska, Tomasz Fopke, Janina Kurowska (fot. Anna Kąkol)

z wywiadów stwierdził bowiem, że „człowiek zna dobrze tylko jeden język! Trzeba czuć dźwięk, melodię, fonetykę. Ja mówię dobrze tylko po kaszubsku” [„Gazeta Dolnośląska” 1999: 6].

Stworzeniem scenariusza wystawy zajął się powołany przez dyrektora wejherowskiego Muzeum Tomasza Fopke zespół kuratorski ${ }^{12}$ w składzie: Janina Kurowska - przewodnicząca, Tomasz Fopke, Zuzanna Szwedek-Kwiecińska, Justyna Grabowska-Szmelc, a także autor niniejszego tekstu ${ }^{13}$. Koordynatorem projektu wystawienniczego był gdański historyk, Andrzej Hoja. Prace nad owym scenariuszem zarówno w formie spotkań roboczych jak i prac indywidualnych miały miejsce od czerwca 2017 do września 2020 r.

Co to oznacza w narracyjnej praktyce? Chodzi o to, aby pisać i opowiadać historię owej wspólnoty z perspektywy ludzi, a nie miejsca, które zamiesz-

\footnotetext{
${ }^{12}$ Zarządzenie nr 1/2017 z dnia 16 czerwca 2017 roku Dyrektora Muzeum Piśmiennictwa i Muzyki Kaszubsko - Pomorskiej w Wejherowie.

${ }^{13}$ Pełna lista osób zaangażowanych w powstanie wystawy stałej, a także instytucji, które użyczyły zabytki lub ich reprodukcje znajduje się na stronie internetowej Muzeum Piśmiennictwa i Muzyki Kaszubsko-Pomorskiej w Wejherowie. https://www.muzeum.wejhe rowo.pl/d/ksiaznica/realizatorzy-i-partnerzy-projektu/realizatorzy-i-partnerzy-projektu/? cat=67. [dostęp 13.11.2021 r.].
} 
kują, bo to w ciągu ostatniego tysiąclecia było zmienne. Niegdyś ojczyzną Kaszubów w sensie terytorialnym było Pomorze Zachodnie i Wschodnie, a więc władztwo Gryfitów [Kozłowski 1985] i Sobiesławiców [Śliwiński 2019] funkcjonujące między polityczną niezależnością, a jej utratą na rzecz niemieckiej [Samsonowicz 1991: 109-174; Popielas-Szultka 2000: 215-231; Szultka 2000: 235] lub polskiej państwowości ${ }^{14}$.

Profesor Gerard Labuda w toku wieloletnich dociekań sformułował wniosek mówiący o tym, że „Kaszubi jako lud sa tożsami etnicznie z Pomorzanami, jednakże w toku rozwoju dziejów historycznych pojęcie Pomorzan nabiera znaczenia wielonarodowościowego $w$ wyniku procesów migracyjnych i wynaradawiających, związanych z napływem na tę ziemię ludności polskiej, niemieckiej, skandynawskiej, szkockiej, angielskiej i bałtyjskiej. Po utracie swej własnej państwowości w XIII wieku Kaszubi przestali być gospodarzami tej ziemi i stali się tylko jednym z jej składników” [Labuda 2006: 37]. Labuda zauważa, iż to zespół zdarzeń i procesów, które miały wówczas miejsce zaważyły także na historycznej narracji. Kaszubi/Pomorzanie „będąc początkowo podmiotem dziejów swej ojczyzny, z czasem stali się przedmiotem tej historii” [Labuda 2006: 37].

Historia Kaszubów miała stać się jednym z przewodnich tematów wystawy. Jej adresatem jest młodzież oraz dorośli, zarówno osoby które dysponują pewną wiedzą o Kaszubach jak i ci, którzy nie mają jej wcale. Temat ten jest bardzo złożony i trudny, a dopasowanie przekazywanych treści przy pomocy tekstów, zabytków czy multimediów do percepcji i zdolności poznawczych osób zwiedzających było ogromnym wyzwaniem. W muzealnym zespole roboczym pojawiło się więc pytanie w jaki sposób opowiedzieć historię naukowca, dla którego dziełem życia były dzieje społeczności, której sam był częścią. Po wielu miesiącach prac zdołano wypracować scenariusz wystawy będący połączeniem biografii jak i historii tej pomorskiej społeczności. Członkowie zespołu starali się jak najlepiej pojąć metodologię Gerarda Labudy niewątpliwie wyznaczającego nowy standard historycznego opisu upodmiotawiającego badaną grupę społeczną. Do rozstrzygnięcia pozostaje kwestia na ile ten zabieg muzealnikom się powiódł. Wystawa jak dotąd nie doczekała się merytorycznej oceny i zapewne konstruktywnej krytyki ze strony specjalistów.

\footnotetext{
${ }^{14} \mathrm{~Np}$. według terminologii Gerarda Labudy po tzw. drugim piastowskim podboju w XII w., czy też po akcie inkorporacji Pomorza Gdańskiego rozpoczynającego wojnę trzynastoletnią w drugiej połowie XV wieku. (G. Labuda 2006: 91, 453].
} 


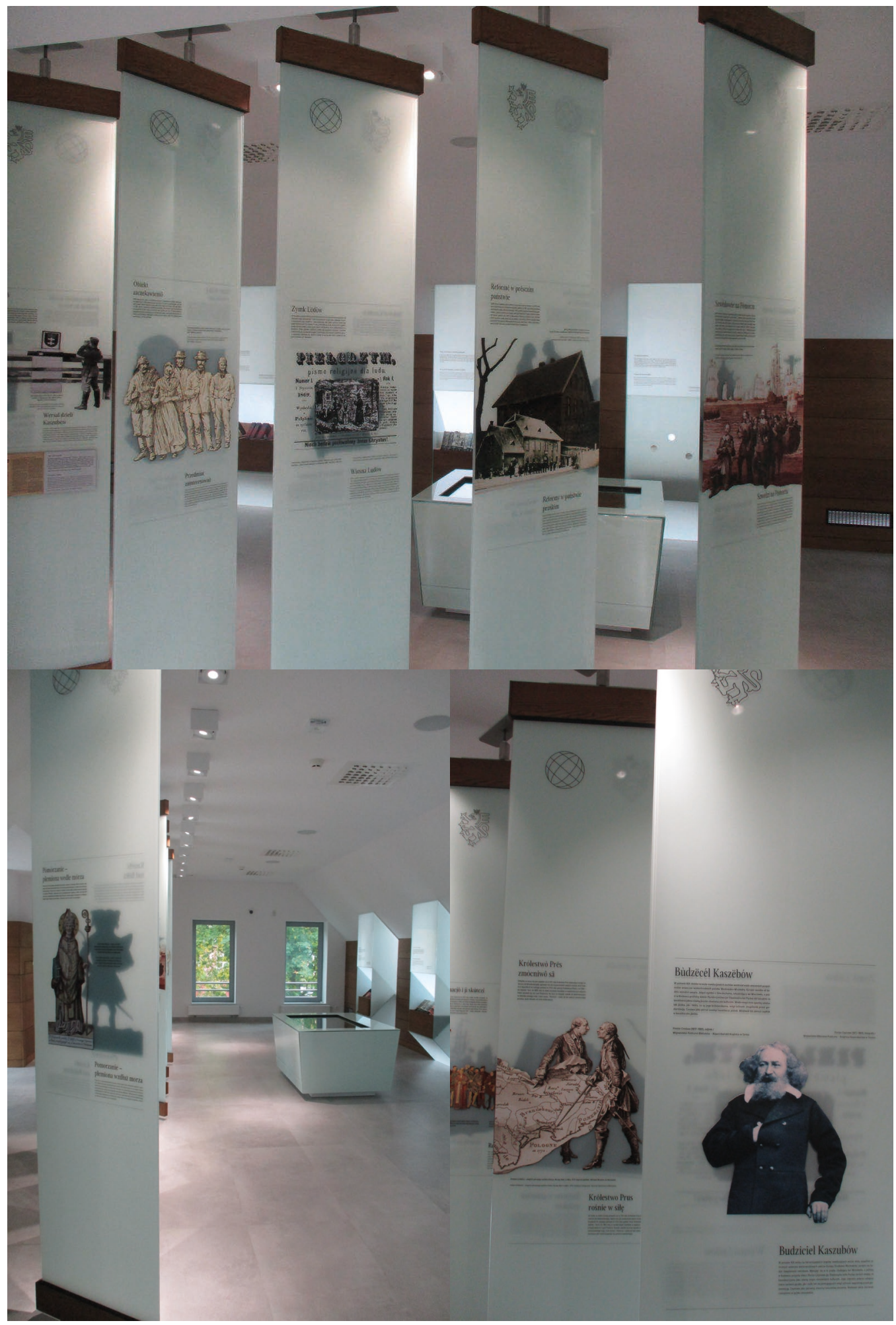

Il. 3-5. Obrotowe ekspozytory prezentujące historię Kaszubów w Książnicy profesora Gerarda Labudy w Wejherowie (fot. Mateusz Szuba) 
Najważniejsze wątki dziejów Kaszubów zostały opowiedziane przy pomocy dwunastu obrotowych ekspozytorów zainstalowanych na sali wystawy stałej w Książnicy ${ }^{15}$. Co niezwykle istotne, tu także opowiedziano tę historię przy pomocy dwóch języków, a więc wiodącego kaszubskiego oraz pomocniczego polskiego. Każda z obrotowych plansz została zaprojektowana w taki sposób, aby z pomocą prostego ruchu ręką poznać narrację istotnego wydarzenia w historii Kaszubów opowiedzianej z dwóch perspektyw.

W pierwszej podmiotem narracji są Kaszubi. To oczami tej społeczności opowiedziano o takich wydarzeniach jak reformacja, Wiosna Ludów czy sytuacja Kaszubów w okresie dwudziestolecia międzywojennego oraz niemieckiej okupacji w latach II wojny światowej. Autorzy kilkudziesięciu zaprezentowanych na ekspozytorach tekstów podjęli próbę takiego opisu. Pierwszy przykład zastosowania tej narracyjnej metody znajduje się poniżej:

\section{Reformy w państwie pruskim}

Upadek Rzeczypospolitej sprawił, że Kaszubi z Pomorza Gdańskiego stali się od 1772 roku poddanymi Króla Prus (w Gdańsku dopiero od 1793). Nowa przynależność państwowa dzięki reformom rolnym w XIX wieku przyczyniła się do ogromnych zmian społecznych i własnościowych wśród Kaszubów. Po pierwsze kaszubscy gospodarze rolni dopiero teraz stali się pełnoprawnymi właścicielami uprawianej ziemi, ustawała również ich powinność wobec dworu (czynsze daniny, pańszczyzna) czy Kościoła, którego dobra teraz przejęło państwo. Wprowadzenie obowiązkowego nauczania dzieci i szybki rozwój szkolnictwa po 1870 roku niemal zlikwidowały problem analfabetyzmu ${ }^{16}$.

Dowiadujemy się tu w jaki sposób kaszubska społeczność radziła sobie w procesie tzw. „pruskiej drogi do kapitalizmu [Labuda 1996: 114] i w jaki sposób skorzystała również z cywilizacyjnego postępu systemowo budowanego przez zaborcze państwo.

Po drugiej stronie obrotowej planszy znajduje się tzw. perspektywa zewnętrzna. Autorzy wystawy podjęli tu próbę narracyjnego zabiegu mającego pokazać, w jaki sposób dotąd opowiadano i wciąż pisze się o Kaszubach w literaturze naukowej i popularnonaukowej. Działo się to zazwyczaj

\footnotetext{
${ }^{15}$ Tę terminologię zastosował projektant wystawy stałej.

${ }^{16}$ Tekst zamieszczony na obrotowym ekspozytorze nr 6 na wystawie stałej w Książnicy profesora Gerarda Labudy.
} 
w kontekście dziejów Niemiec, ale też Danii, Szwecji, szeroko pojętego Pomorza i wreszcie historii Polski ${ }^{17}$.

\section{Królestwo Prus rośnie w siłę}

Od kiedy na mapie Europy pojawiło się w 1701 roku Królestwo Prus (obejmujące swym terytorium też Brandenburgię), dążyło ono do poszerzenia swych terytoriów. Król Fryderyk II przyłączył do swojego państwa w 1772 roku polskie Prusy Królewskie, a w 1793 - także Gdańsk i Toruń. Do 1815 roku w wyniku klęski Szwedów w wojnach napoleońskich Prusy Przejęły także ich część Pomorza. Kaszubi znaleźli się w ten sposób administracyjnie na terytorium jednego kraju. A ich ziemia - Pomorze - miała się stać zapleczem rolniczym i żywnościowym dla modernizującego się państwa niemieckiego ${ }^{18}$.

Kolejnym przykładem zastosowania perspektywy wewnętrznej/podmiotowej jest temat Między Polską a Niemcami, w którym czytamy:

W końcu XIX wieku na Pomorzu Gdańskim nasilały się procesy germanizacyjne. Reakcją na nie był narodowy ruch polski kształtujący się i zyskujący przewagę wśród lokalnych elit. Kaszubi nadal jednak nie wypracowali jednoznacznej strategii działań na rzecz ocalenia swojej tożsamości. Próbą odbudowy ruchu kaszubskiego było powołanie w 1912 roku Towarzystwa Młodokaszubów, którego liderem był pochodzący z Kościerzyny Aleksander Majkowski. Opowiedzieli się oni za wspólnotą narodową z Polakami. Nie zrezygnowano jednak z pracy organicznej na rzecz rozwoju odrębności i działań w obrębie specyficznej kultury dominującej na Kaszubach, tak aby „podnieść ludność kaszubską pod względem kulturalnym, gospodarczym i politycznym ${ }^{19}$.

Fakt pojawienia się na początku XX w. Towarzystwa Młodokaszubów w szeroko pojętym ruchu kaszubsko-pomorskim nie może ujść uwadze

\footnotetext{
${ }^{17}$ W swoich naukowych dociekaniach Gerard Labuda stwierdził, że przykładem przedmiotowego potraktowania dziejów Kaszubów jest monografia Friedricha Lorentza, Geshichte der Kaschuben z 1926 r. Ta — według Labudy — zajmować się miała „głównie szerzeniem się niemczyzny na całym Pomorzu, z Kaszubami jako tłem”. Gerard Labuda był też głęboko przekonany, że i Historia Pomorza w stopniu głęboko niewystarczającym lub wręcz pobieżnym opisuje historię Kaszubów: „W tym miejscu muszę samokrytycznie powiedzieć, że $w$ redagowanych przeze mnie tomach wielkiej syntezy Historia Pomorza tematyka kaszubska pojawia się incydentalnie i, użyjmy tu znowu tego określenia „deficytowo”. Działaty tu dwa czynniki. Synteza ta była pisana z punktu widzenia integracji „ziem odzyskanych” z Macierza oraz nie bez nacisku autocenzury w sprawach kaszubskich”.

${ }^{18}$ Tekst zamieszczony na obrotowym ekspozytorze nr 6 na wystawie stałej w Książnicy profesora Gerarda Labudy.

${ }^{19}$ Tekst zamieszczony na obrotowym ekspozytorze nr 8 na wystawie stałej w Książnicy profesora Gerarda Labudy.
} 
badaczom historii Kaszubów. To też w swych licznych postulatach i konspektach dot. dziejów tej społeczności sygnalizował nie tylko patron tytułowej placówki [Labuda 1996: 41-48]. W tekście wspomniano też o rzeczy niezwykle istotnej - pracy organicznej stanowiącej jedyną skuteczną obronę Kaszubów przed agresywną germanizacją obserwowaną zwłaszcza od siódmej dekady dziewiętnastego stulecia. Tarczą chroniącą przed tą wynaradawiającą machiną miało być m.in. samokształcenie, organizacja bibliotek ludowych, zakładanie kółek rolniczych, wydawanie i czytanie prasy. We wszystkich tych polach notowano aktywną działalność Kaszubów [Borzyszkowski 2000: 281-287].

Po drugiej stronie obrotowej planszy podjęto próbę opisu wydarzeń wówczas istotnych dla ludzi opisujących Kaszuby i Kaszubów, szczególnie zaś naukowo zainteresowanych kaszubską mową u schyłku XIX w., o czym poniżej:

\section{Przedmiot zainteresowań}

Druga połowa XIX wieku w państwie niemieckim charakteryzowała się polityką zacierania różnic pomiędzy poszczególnymi narodami zamieszkującymi jego terytorium. Na dawnych ziemiach Rzeczpospolitej najpierw ograniczono naukę języka polskiego, a w 1887 roku całkowicie usunięto go ze szkół. Ale właśnie w tym czasie kaszubszczyzną zainteresowali się nie tylko ludzie próbujący ją ratować od wewnątrz, ale i naukowcy spoza tej społeczności. Prace etnograficzne prowadził tu już w połowie XIX wieku rosyjski badacz Aleksander Hilferding, a pochodzący z Małopolski Stefan Ramułt wydał w 1893 roku Słownik języka pomorskiego czyli kaszubskiego ${ }^{20}$.

Osią narracji uczyniono najważniejsze wydarzenia i punkty zwrotne w historii Kaszubów, ale też długofalowe procesy społeczno-gospodarcze kształtujące rozwój kaszubskiej społeczności na przestrzeni ostatnich stuleci. Wystarczy wymienić wprowadzanie chrześcijaństwa na Pomorzu podczas tzw. drugiego piastowskiego podboju ${ }^{21}$, wpływ kulturowy państwowości niemieckiej czy to pod postacią Brandenburgii, Państwa Krzyżackiego czy też Królestwa Prus [Salmonowicz 1987: 390-420], Cesarstwa Niemiec [Krasuski 2004: 230] i nazistowskiej Rzeszy Niemieckiej [Labuda 2006: 91].

\footnotetext{
${ }^{20}$ Tamże.

${ }^{21}$ Tak ten proces nazywał Gerard Labuda [Labuda 2006: 91 i n.]
} 
Testament naukowy Gerarda Labudy dekadę po jego śmierci został niemal zupełnie wypełniony. Mowa tu oczywiście o kolejnych tomach Historii Kaszubów autorstwa profesorów Józefa Borzyszkowskiego [Borzyszkowski 2019, a, b, c] i Cezarego Obracht-Prondzyńskiego [Obracht-Prondzyński 2019]. Wszystkie opublikowane dotąd tomy znalazły swoje miejsce w jednym z ekspozytorów wnękowych na wystawie stałej Książnicy. Jest tu też pewne intrygujące puste miejsce. Jest ono przeznaczone na niewydany jeszcze, a spodziewany w przyszłym roku drugi tom Historii Kaszubów autorstwa Zygmunta Szultki ${ }^{22}$. W sąsiednim ekspozytorze jest też miejsce dla równie ambitnego wieloautorskiego dzieła zainicjowanego w latach sześćdziesiątych XX w. przez Gerarda Labudę, tj. serii naukowej Historia Pomorza.

Kolejną instalacją mającą nieco przybliżyć najważniejsze dziejowe momenty w historii Kaszubów jest interaktywna mapa multimedialna, która w zamyśle jej pomysłodawców i autorów ma prezentować zmienny obszar występowania Kaszubszczyzny na tle równie zmiennych organizmów politycznych istniejących na południowym wybrzeżu Bałtyku między Rugią a ujściem Wisły w Zatoce Gdańskiej. Większość mapek wraz z towarzyszącymi im animacjami opracowano m.in. na podstawie Atlasu autorstwa Jana Mordawskiego [Mordawski 2017]. Na interaktywnym monitorze szybko spostrzeżemy oś czasu z wpisanymi datami — w zamyśle autorów — najważniejszymi z punktu widzenia kaszubskiego etnosu na szeroko pojętym Pomorzu nad południowym Bałtykiem. Rzecz jasna nie zawsze jest to periodyzacja zbieżna z tą znaną z historii Polski, co również jest próbą podmiotowego ujęcia. Na wspomnianej osi wyszczególniono m.in. rok 1123, 1640, 1871 czy 1920. Pierwsza z dat to zakończenie procesu tzw. drugiego piastowskiego podboju Pomorza dokonanego za sprawą piastowskiego księcia Bolesława Krzywoustego. Przechodząc do roku 1640 poznajemy mapę polityczną Pomorza niedługo po śmierci ostatniego władcy z pomorskiej dynastii Gryfitów - Bogusława XIV. Trzecia z wymienionych dat to też ważna cezura w historii Niemiec [Kizwalter 2007: 245-248]. Wówczas pod egidą Prus doszło do procesu określanego w historiografii mianem Zjednoczenia Niemiec i restauracji Cesarstwa Niemiec [Andrzejewski 2003: 39-40]. Od 1871 r. każdy kolejny król Prus z dynastii Hohenzollernów był też Cesarzem [Borzyszkowski 2019 b: 7].

\footnotetext{
${ }^{22}$ Zygmunt Szultka przygotowuje kilkuczęściowy tom II dot. lat 1525-1815, którego publikacja planowana jest w $2022 \mathrm{r}$.
} 


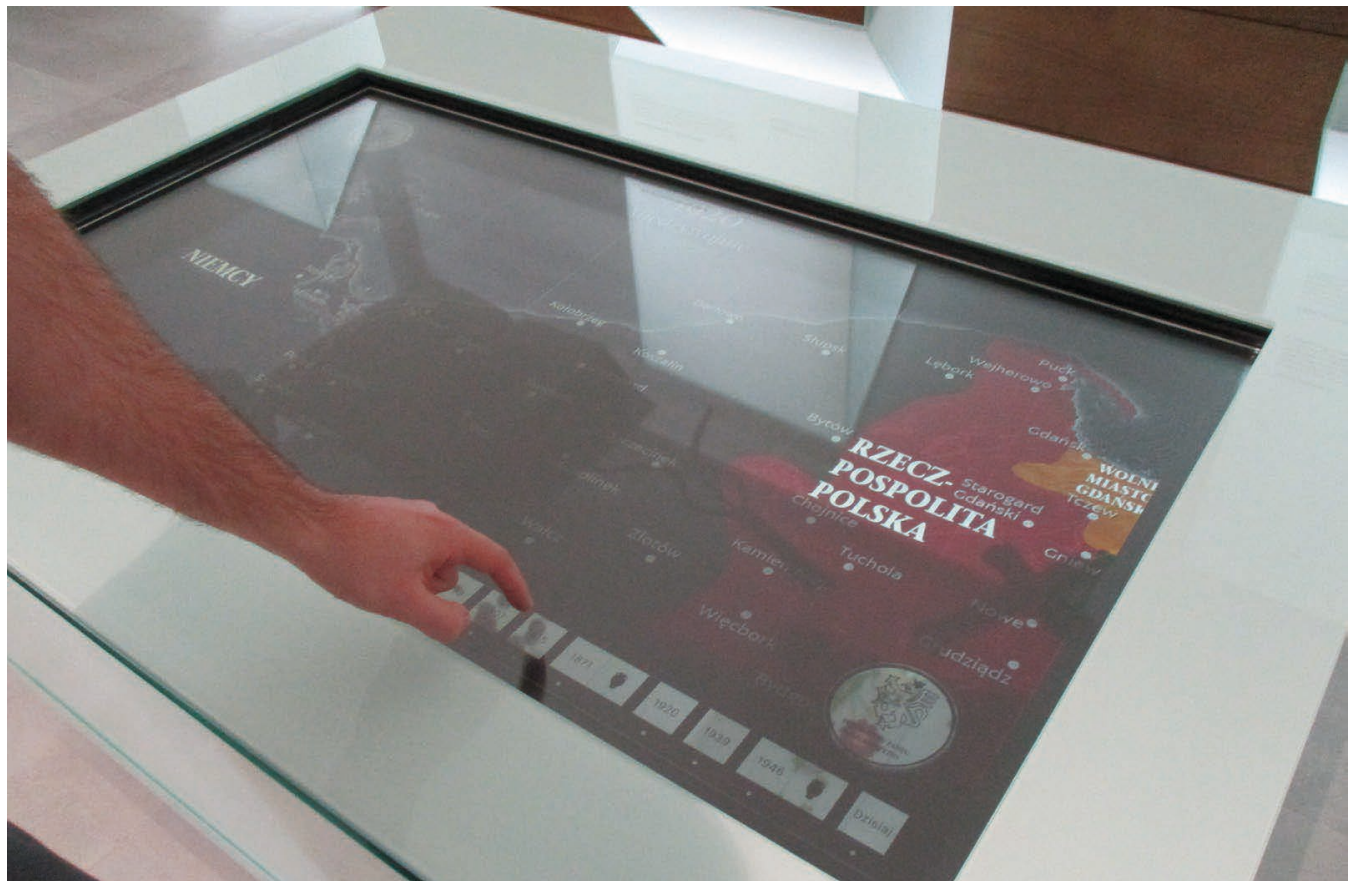

Il. 6. Instalacja interaktywnej mapy multimedialnej w Książnicy profesora Gerarda Labudy (fot. Mateusz Szuba)

Zaborcze państwo stawało się więc znacznie silniejsze, zdecydowanie bardziej spoiste a polityka kulturalna i narodowościowa praktykowana przez architekta owego zjednoczenia, kanclerza Otto von Bismarcka spychała Kaszubów coraz bardziej na margines życia społecznego, gospodarczego, kulturalnego, religijnego [Borzyszkowski 2019 b: 7-120]. To data bardzo ważna w historii Kaszubów, choć nie tak istotna w historii Polski. Odtąd też każdy Kaszuba, najczęściej mieszkaniec pomorskiej Prowincji Prusy Zachodnie był poddanym Cesarza Niemiec aż do upadku Cesarstwa w 1918 r.

Inne jest też podejście do kwestii zaprowadzenia państwowości polskiej na części Pomorza Nadwiślańskiego. W przypadku Kaszub rzecz nie dotyczy roku 1918, a 1920 [Kutta 2003: 75; Kosiński 2002: 72-100]. Jak można zaobserwować, Kaszubi bytowscy i lęborscy nie stali się obywatelami odrodzonego państwa polskiego. Ten status prawny stał się faktem w 1945 r., a więc po niemal 300 latach przymusowego trwania w państwowości niemieckiej [Szultka 1998]. Kaszubi gdańscy, sopoccy, w dwudziestoleciu międzywojennym również nie mieszkali w granicach Polski. Byli — jak wiemy obywatelami Wolnego Miasta Gdańsk [Stępniak 1991: 10-50], co również uzmysławia nam choćby pobieżne zapoznanie się z interaktywną aplikacją. Spoglądając na mapę, łatwo również zrozumieć dlaczego międzywojenne 
województwo pomorskie w niemieckiej propagandzie (zarówno w czasach tzw. Republiki Weimarskiej czy III Rzeszy Niemieckiej) funkcjonowało pod nazwą polskiego korytarza (niem. polnischer korridor) i dlaczego zagrożenie niemiecką agresją było szczególnie wielkie dla mieszkańców ówczesnego województwa pomorskiego [Wakar 2000: 79-144].

Kontekst roku $1945 \mathrm{r}$. jest tu istotny z kilku zasadniczych powodów. Po raz pierwszy Kaszubi/Pomorzanie, w całości stali się mieszkańcami jednego państwa - Polski. Po drugie w owym roku i kolejnych latach nastąpiła zmiana zarysu zasięgu Kaszubszczyzny poprzez jego wyraźne przesunięcie na zachód ${ }^{23}$. Przyglądając się mapie możemy szybko wywnioskować, że Kaszubi utracili związki z państwem polskim już podczas pierwszego rozbioru w 1772 r. i zaczęli funkcjonować w jednej z części składowych Królestwa Prus -Prowincji Prusy Zachodnie [Wajda 1991: 175]. W rzeczonym roku również dzięki ustaleniom poczynionym przez Jana Mordawskiego [Mordawski 2017] możemy zaobserwować ówczesny zasięg Kaszubszczyzny po naciśnięciu interaktywnego przycisku znajdującego się na wyświetlaczu mapy. To narzędzie pozwala nam czytelnie zobrazować w jakich organizmach państwowych na przestrzeni wieków przyszło żyć społeczności kaszubskiej i jakie ogólne procesy sprawiły, że dziś zamieszkują Pomorze Gdańskie, województwo pomorskie nie licząc oczywiście Kaszubów przebywających na emigracji [Borzyszkowski 2004].

Aby ułatwić poruszanie się po mapie zastosowano też tzw. pogłębienia, a więc teksty oraz ikonografię, których celem jest wyjaśnienie zawiłych kwestii związanych z historią Pomorza, historią Kaszubów.

Za istotny w tej narracji uznano także rok 1999. Wówczas na mocy ustawy i jej rozporządzeń wykonawczych na mapie administracyjnej Polski doszło do bardzo istotnych zmian. Z istniejących 49 województw utworzono $16^{24}$. Pomorze Gdańskie zostało wpisane w granice województwa pomorskiego $^{25}$ ze stolicą w Gdańsku, mieście które przez ponad 50 powojennych lat

\footnotetext{
${ }^{23} \mathrm{~W}$ wyniku międzynarodowych ustaleń, a w ślad za nimi idących rozporządzeń krajowych i regionalnych przeprowadzono rozpiętą na wiele miesięcy akcję deportacji ludności niemieckiej z Pomorza Gdańskiego do Niemiec, co istotnie zmieniło krajobraz kulturowy Kaszub. Mowa tu także o procesie tzw. migracji wewnętrznej, a więc zasiedlania przez Kaszubów Ziemi Lęborskiej czy Bytowskiej opuszczonej przez Niemców. (szerzej o tym: [Obracht-Prondzyński 2017: 95; 2002: 135-220; 2016: 63-74].

${ }^{24}$ Ustawa z dnia 25 lipca 1998 r. o wprowadzeniu trójstopniowego podziału terytorialnego państwa, Dz. U. nr 96, poz. 603.

${ }^{25}$ Współczesne województwo pomorskie posiada też herb, którym jest postać mitycznego Gryfa stanowiącego również motyw przewodni w herbie Kaszub. Nazwa województwa nawiązuje do istniejącej jednostki administracyjnej o tożsamej nazwie istniejącej na terenie
} 
pełniło funkcję stołeczną dla województwa gdańskiego. Przywrócono też trzystopniowy podział administracyjny.

Mapa nie jest tylko interaktywną aplikacją. Tę instalację wyposażono też w oryginalne zabytki kultury materialnej pochodzące z zasobów wejherowskiego Muzeum, a także Muzeum Archeologicznego w Gdańsku, Muzeum - Kaszubskiego Parku Etnograficznego im. Teodory i Izydora Gulgowskich we Wdzydzach Kiszewskich oraz ze zbiorów prywatnych. Ponadto odnaleźć tu można cyfrowe reprodukcje pocztówek, obrazów, ilustracji z krótkimi komentarzami, których zadaniem jest - w przekonaniu autorów ekspozycji - wyjaśnienie zawiłych kwestii związanymi z Historią Kaszubów w dziejach Pomorza.

Puentą kończącą narrację aplikacji mapy są przytoczone poniżej słowa Gerarda Labudy, które chyba najlepiej oddają zmienność występowania Kaszubszczyzny nad wybrzeżem południowego Bałtyku: „Całe Pomorzeod Odry po Gdańsk - to były Kaszuby, to jest ojczyzna Kaszubów. Ale ci na zachodzie zostali zniemczeni [...] Rdzenni Kaszubi ostali się tylko we wschodniej części Pomorza. Ta wysepka tutaj ocalała”. Aplikacja mapy multimedialnej została stworzona przede wszystkim dlatego, aby dynamikę tej zmiennej pokazać, unaocznić w ogólnodostępnej muzealnej przestrzeni. Niezwykle ważna jest tu konieczna interakcja osoby zwiedzającej z multimedialnym narzędziem.

Istotnym elementem ekspozycji stałej w Książnicy są gabloty szufladowe i wnękowe. To w nich znalazły swoje miejsce oryginalne artefakty mówiące wiele o życiu prof. Gerarda Labudy, zwłaszcza zaś o naukowym warsztacie i dokonaniach badawczych kaszubskiego mediewisty, który większość życia spędził w Poznaniu. To przestrzeń, w której możemy poznać historię Gerarda Labudy, który jeszcze jako student stał się recenzentem wydanej w 1938 r. Historii Kaszubów, autorstwa dra Aleksandra Majkowskiego, twórcy najwybitniejszego dzieła literatury kaszubskiej, epopei Żëcé i przigòdë Remùsa (pol.: Życie i przygody Remusa). Wśród wielu wątków poruszonych w tej biograficznej narracji należy zwrócić uwagę i na historię rodzącej się pasji zbierania książek i czasopism naukowych przez młodego Labudę, a tym samym dojrzewania do roli profesjonalnego historyka.

I Rzeczypospolitej od połowy XV wieku. W Drugiej Rzeczypospolitej powrócono do tej nazwy. Po II wojnie światowej także reaktywowano województwo pomorskie ze stolicą początkowo w Toruniu, od kwietnia 1945 r. w Bydgoszczy. Od 30 marca z jego obszaru wydzielono województwo gdańskie. W 1950 r. województwo pomorskie zniknęło z mapy administracyjnej Polski. 


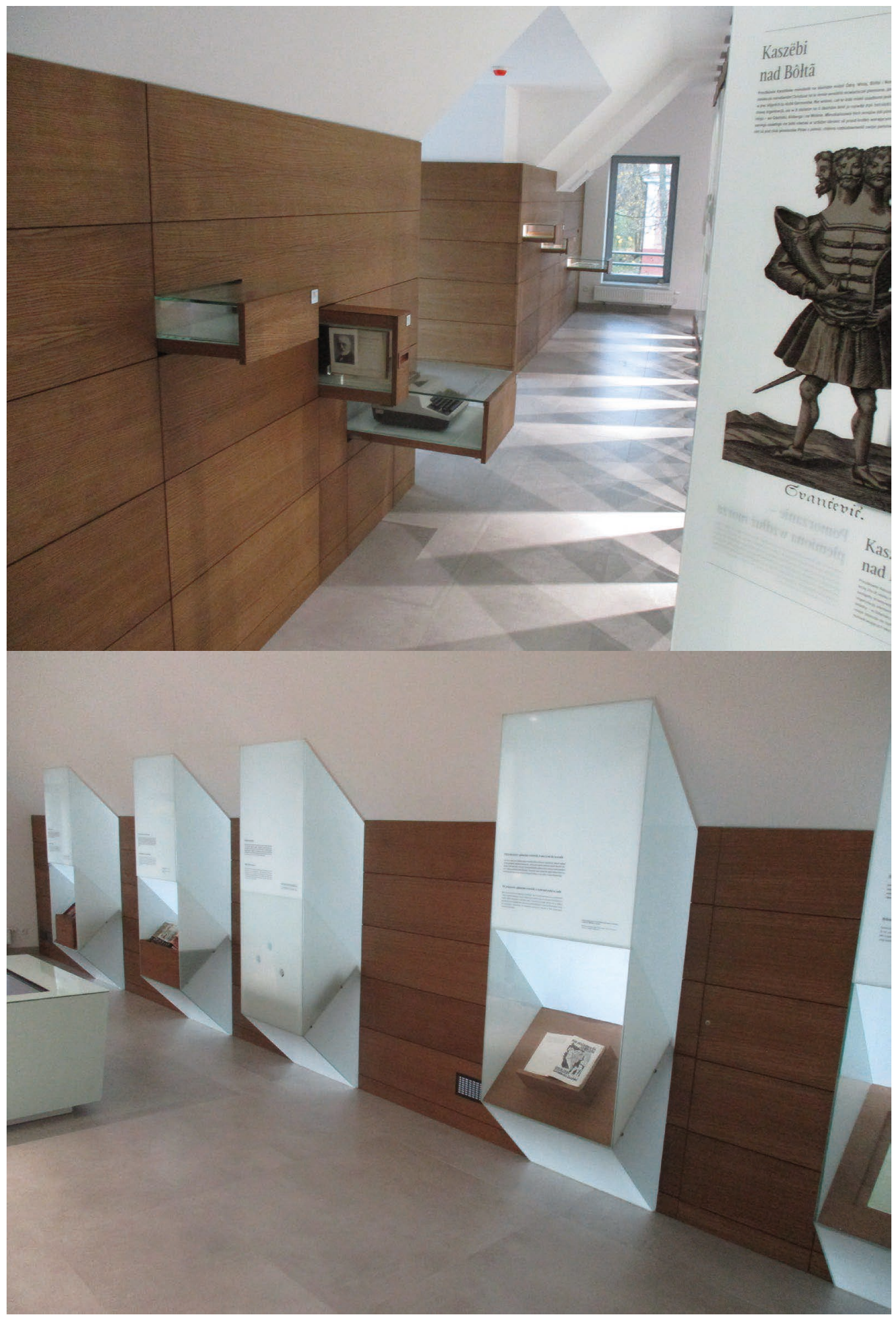

Il. 7-8. Gabloty szufladowe i wnękowe na wystawie stałej w Książnicy profesora Gerarda Labudy (fot. Michał Hinc) 
Na koniec, zachęcając do częstych i licznych odwiedzin obiektu, warto dodać, że Muzeum Piśmiennictwa i Muzyki Kaszubsko-Pomorskiej w Wejherowie zostało docenione podczas tegorocznej 41. edycji Konkursu na Wydarzenie Muzealne Roku Sybilla 2020, którego organizatorem był Narodowy Instytut Muzealnictwa i Ochrony Zabytków pod patronatem Ministra Kultury, Dziedzictwa Narodowego i Sportu prof. Piotra Glińskiego. Wejherowskie Muzeum zdobyło wyróżnienie w kategorii nowe i zmodernizowane wystawy stałe za ekspozycję „Wystawa stała w Książnicy profesora Gerarda Labudy w Wejherowie”26.

\section{Bibliografia}

\section{Andrzejewski Marek}

2003: Od Bismarcka do Schrodera. Portrety niemieckich kanclerzy, Gdańsk: Wydawnictwo Uniwersytetu Gdańskiego.

\section{Borzyszkowski Józef}

1991: Dzieje własne Kaszubów, w: O uprawianiu i znaczeniu historii regionalnej, red. C. Niedzielski, Toruń-Ciechanów.

2000: Kaszubi i Pomorze w XIX i XX wieku, w: Pomorze - mała ojczyzna Kaszubów (Historia i współczesność), red. J. Borzyszkowski, D. Albrecht, Gdańsk, Lubeka: Zrzeszenie Kaszubsko-Pomorskie, Instytut Kaszubski w Gdańsku, Ostsee-Akademie.

2004: O Kaszubach w Kanadzie, Gdańsk-Elbląg: Instytut Kaszubski w Gdańsku.

2006: Gerard Labuda - Kaszuba z Poznania. Droga od „Historii Pomorza” do „Historii Kaszubów”, „Przegląd Zachodni” 2006, nr 1.

2011: Kaszubsko-pomorska droga badań naukowych Profesora Gerarda Labudy (1916-2010), w: Pro memoria Gerard Labuda (1916-2010), oprac. J. Borzyszkowski, Gdańsk-Wejherowo: Instytut Kaszubski.

a 2019: Historia Kaszubów w dziejach Pomorza. Tom III. Część 1. W Królestwie Pruskim i Cesarstwie Niemieckim (1815-1920), Gdańsk: Instytut Kaszubski.

b 2019: Historia Kaszubów w dziejach Pomorza, Tom III. Część 2 . W Cesarstwie Niemieckim —oraz za Wielką Wodą na emigracji (1871-1920), Gdańsk: Instytut Kaszubski w Gdańsku.

c 2019: Historia Kaszubów w dziejach Pomorza. Tom IV. Kaszubi w II RP i w latach II wojny światowej (1920-1945), Gdańsk: Instytut Kaszubski w Gdańsku.

\section{Breza Bogusław}

2000: Muzeum Piśmiennictwa i Muzyki Kaszubsko-Pomorskiej $w$ Wejherowie $w$ trzydziestoleciu, w: Muzea, a dziedzictwo kulturowe Pomorza, red. J. Borzyszkowski, Gdańsk-Wejherowo: Instytut Kaszubski w Gdańsku, Muzeum Piśmiennictwa i Muzyki Kaszubsko-Pomorskiej w Wejherowie.

\footnotetext{
${ }^{26}$ Laureaci SYBILLA 2020 (nimoz.pl), [dostęp 10.11.2021 r.].
} 


\section{Fopke Tomasz}

2017: Spuścizna Gerarda Labudy w muzeum wejherowskim. Budowa książnicy i obchody Roku Gerarda Labudy — kalendarium dokonań, „Acta Cassubiana” T. 19.

\section{Hinc Michal, Adam Lubocki}

2021: Książnica profesora Gerarda Labudy w Wejherowie jako muzealny ośrodek badań naukowych [tekst pokonferencyjny, w druku].

\section{Kamiński Edmund}

1971: Geneza i działalność Muzeum Piśmiennictwa i Muzyki Kaszubsko-Pomorskiej $w$ Wejherowie, „Pomerania”.

\section{Kizwalter Tomasz}

2007: Historia powszechna. Wiek XIX, Warszawa: Wydawnictwo „Trio”.

\section{Kosiński Paweł}

2002: Prusy Zachodnie 1914, Pomorze 1920. Ludność regionu wobec przemian politycznych okresu I wojny światowej, Warszawa: Wydawnictwo NERITON

\section{Kozłowski Kazimierz}

1985: Gryfici, książęta Pomorza Zachodniego, Szczecin

\section{Krasuski Jerzy}

2004: Historia Niemiec, Wrocław

\section{Kutta Janusz}

2003: Druga Rzeczpospolita i Kaszubi 1920-1939, Bydgoszcz

\section{Labuda Gerard}

1970: Gdańsk jako ośrodek kultury w przeszłości, „Rocznik Gdański”, T. 29-30.

1989: Historia Kaszubów na tle historii Pomorza, „Pomerania”, nr 2.

1991: O Aleksandra Majkowskiego „Historii Kaszubów”, Gdańsk.

1992: II Kongres Kaszubski „Przyszłość Kaszubszczyzny”: dokumentacja, oprac. J. Łuczkowska, C. Obracht-Prondzyński, W. Popiołek, Gdańsk.

1996: Kaszubi i ich dzieje, Gdańsk: Oficyna Czec, Rada Miasta Wejherowa, Zrzeszenie Kaszubsko-Pomorskie.

1999: Jestem Kaszubą w Poznaniu. Z Profesorem Gerardem Labudą rozmawia Beata Maciejewska, „Gazeta Dolnośląska”, 15 września 1999.

2000: Zapiski kaszubskie, pomorskie i morskie, Gdańsk: Oficyna Czec.

2001: O Pomorzu jako ojczyźnie Kaszubów. Dzieło nowatorskie, „Acta Cassubiana” T. 3. 2002: Historia dyplomacji polskiej X-XX w., red. G. Labuda, W. Michowicz, Warszawa 2002.

2006: Historia Kaszubów w dziejach Pomorza. T 1. Czasy średniowieczne, Gdańsk: Instytut Kaszubski

2007: Kaszubi w dziejach Pomorza, „Pomerania”, nr 1.

\section{Labuda Pawel}

1972: Powstanie i działalność MPiMK-P w Wejherowie w latach 1968-1971 oraz główne kierunki działania $w$ latach 1972-1975, „Informator Muzeum Piśmiennictwa i Muzyki Kaszubsko-Pomorskiej”.

\section{Lubocki Adam}

2021: Książnica Profesora Gerarda Labudy przy Muzeum Piśmiennictwa i Muzyki Kaszubsko-Pomorskiej w Wejherowie, „Nasze Historie”, nr 21, 2021 (tekst w druku). 


\section{Łukomski Grzegorz}

2000: Problem „korytarza” w stosunkach polsko-niemieckich ina arenie międzynarodowej 1919-1939. Studium polityczne, Warszawa

\section{Majkowski Aleksander}

1938: Historia Kaszubów, Gdynia

\section{Małłek Janusz}

2000: Wielkie Pomorze (Pomorze Zachodnie, Prusy Zachodnie $i$ Wschodnie) $w$ historiografii polskiej po roku 1945, w: Doświadczenie przeszłości. Niemcy w Europie Środkowo-Wschodniej w historiografii po 1945 r. Erfahrungen der Vergangenheit. Deutsche und Ostmitteleuropa im Spigel der Historiographienach 1945, red. J. Kłoczowski, W. Matwiejczyk, E. Mühle, Marburg-Lublin

\section{Michałowski Roman}

2006: Poczatki państwa polskiego w badaniach naukowych Gerarda Labudy, w: Naukowe dzieło Profesora Gerarda Labudy, red. J. Dobosz, Poznań: Wydawnictwo Naukowe UAM

\section{Mordawski Jan}

2017: Atlas dziejów Pomorza i jego mieszkańców - Kaszubów, Gdańsk: Zrzeszenie Kaszubsko-Pomorskie

\section{Notatka...}

2011: Notatka ze spotkania u prof. Gerarda Labudy w dniu 26 kwietnia 2010 roku, [w:] Pro Memoria. Gerard Labuda (1916-2010), oprac. J. Borzyszkowski, Gdańsk-Wejherowo 2011.

\section{Obracht-Prondzyński Cezary}

2008: Kaszubskich pamiatek skarbnice. O muzeach na Kaszubach - ich dziejach, twórcach i funkcjach społecznych, Gdańsk: Instytut Kaszubski w Gdańsku

2016: Specyfika socjogenezy społeczeństwa polskiego nad Dolna Wisła po II wojnie światowej, w: Ziemie nad dolna Wistą. Historia i współczesne wyzwania rozwojowe. W550. Rocznicę II Pokoju Toruńskiego, red. C. Obracht-Prondzyński, Gdańsk-Elbląg

2017: Historia Kaszubów po 1945 r. — refleksje metodologiczne, „Acta Cassubiana” T. 19.

2019: Historia Kaszubów w dziejach Pomorza. Tom V. Dzieje najnowsze (po 1945 r.), Gdańsk: Instytut Kaszubski w Gdańsku.

2002: Kaszubi. Między dyskryminacją a regionalna podmiotowością, Gdańsk: Instytut Kaszubski w Gdańsku

2017: Wielokulturowe Pomorze, wielokulturowy Gdańsk. Szkice z pogranicza, Gdańsk: Instytut Kaszubski w Gdańsku.

\section{Popielas-Szultka Barbara}

2000: Zarys dziejów Pomorza Zachodniego w średniowieczu, w: Pomorze - mała ojczyzna Kaszubów (historia i współczesność), red. J. Borzyszkowski, D. Albrecht, Gdańsk-Lubeka.

\section{Ruchlewski Przemysław}

2019: To Muzeum. 50 lat działalności Muzeum Piśmiennictwa i Muzyki Kaszubsko-Pomorskiej w Wejherowie, Wejherowo-Gdańsk: Muzeum Piśmiennictwa i Muzyki Kaszubsko-Pomorskiej w Wejherowie, Zrzeszenie Kaszubsko-Pomorskie. 


\section{Salmonowicz Stanisław}

1987: Prusy. Dzieje państwa i społeczeństwa, Poznań: Wydawnictwo Poznańskie.

\section{Samsonowicz Henryk}

2006: Gerarda Labudy badania nad historia kultury, w: Naukowe dzieło Profesora Gerarda Labudy, red. J. Dobosz, Poznań.

1991: Z zaścianka w wielki świat. Pomorze Gdańskie - późne średniowiecze (1308-1466), w: Pomorze w dziejach Polski. „Pomorze Gdańskie” T. 19.

\section{Stępniak Henryk}

1991: Ludność polska w Wolnym Mieście Gdańsku (1920-1939), Gdańsk: Wydawnictwo Diecezji Gdańskiej „Stella Maris”.

\section{Szultka Zygmunt}

1998: W lennym i pełnoprawnym władaniu Brandenburgii-Prus (1657/1658-1772/17771815), w: Historia Bytowa, red. M. Szklarkowska, Bytów: Instytut Kaszubski, Zrzeszenie Kaszubsko-Pomorskie.

2000: Kaszubi zachodniopomorscy pod władzą elektorów brandenburskich i królów pruskich do 1806, w: Pomorze i mała ojczyzna Kaszubów. Historia i współczesność, Gdańsk-Lubeka.

\section{Śliwiński Błażej}

2019: Poczet książąt gdańskich. Dynastia Sobiesławiców w XII-XIII wieku, Gdańsk: Wydawnictwo „Marpress”

\section{Wajda Kazimierz}

1991: Oblicze polityczne Prus Zachodnich na przełomie XIX i XX wieku, „Pomorze w dziejach Polski” t. 19, Gdańsk: Gdańskie Towarzystwo Naukowe

\section{Wakar Włodzimierz}

1984: Polski korytarz czy niemiecka enklawa, Olsztyn: Wydawnictwo Pojezierze

\section{Michał Hinc}

\section{About the narration of the history of the Kashubians on the permanent exhibition in Gerard Labuda's Library in Wejherowo}

The article presents the narrative method and the tools of communication about the history of the Kashubians in a new cultural institution in Pomerania and Kashubia - Professor Gerard Labuda's Library belonging to the Museum of Kashubian-Pomeranian Literature and Music in Wejherowo. Years ago, it was this researcher from Kashubia who established that when starting a scientific study of the history of Kashubia, one should write about the history of the Kashubians as the history of the community and the Pomeranian Ethnos. The team preparing the permanent exhibition at the Library also followed this narrative method.

Keywords: Gerard Labuda, permanent exhibition, history of the Kashubians, Museum of Kashubian-Pomeranian Literature and Music, Wejherowo. 
